\title{
Avaliação dos espaços de construção de conhecimento da Escola de Tecnologia da Faculdade Projeção de Brasília
}

\section{Jonathan Rosa Moreira}

\begin{abstract}
Graduação em Bacharelado em Sistemas de Informação pela Faculdade Cenecista de Brasília Campanha Nacional de Escolas da Comunidade MBA em Governança em Tecnologia da Informação pelo Centro Universitário do Maranhão, Especialização Lato Sensu em Educação e Tecnologias para Educação a Distância pela Universidade Cidade de São Paulo, mestrado no curso de Gestão do Conhecimento e da Tecnologia da Informação na Universidade Católica de Brasília
\end{abstract}

Jefferson Bruno Pereira Ribeiro

Graduação em Pedagogia (Licenciatura). Bacharelado em Medicina Veterinária pelas Faculdades Integradas da Terra de Brasília - FTB . Aluno de especialização lato sensu em Planejamento, Implementação e Gestão da EAD, pela Universidade Federal Fluminense - UFF. É mestre em Ciências Medicas, pela Universidade de Brasília - UNB

http://dx.doi.org/10.1590/1981-5344/2043

O conhecimento tem assumido papel de destaque nas organizações e o seu valor reflete diretamente na competitividade e posicionamento no mercado. A falta de entendimento acerca dos processos e de como se estabelece uma comunicação eficaz pode impactar no aprendizado e na cultura organizacionais das Instituições de Educação Superior. Este artigo visa contribuir com um estudo que apresente como a relação entre Comunicação Organizacional, Gestão do Conhecimento, Aprendizagem Organizacional, e Cultura Organizacional pode corresponder um espaço de Construção de Conhecimento para uma Instituição de Educação Superior privada. Trata-se de uma pesquisa com abordagem qualitativa, aplicada no âmbito da Faculdade Projeção, Distrito Federal, para os membros da comunidade acadêmica 
envolvidos em sua Escola de Tecnologia. Em função da revisão de literatura e da análise documental, espera-se propor um modelo de construção de conhecimento para a instituição e avaliar como a Escola de Tecnologia se comporta nesse cenário.

Palavras-chave: Comunicação organizacional; Gestão do conhecimento; Aprendizagem organizacional; Construção de conhecimento.

\section{Assessment of knowledge construction spaces at technology school of the Projeção College in Brasília}

Knowledge has assumed a prominent role in organizations and its value directly reflects the market competitiveness and positioning. The lack of understanding about the processes and how to establish effective communication can impact on learning and organizational culture of Higher Education Institution. This paper aims to contribute with a study that shows how the relationship among Organizational Communication, Knowledge Management, Organizational Learning, and Organizational Culturecan corresponds a space of knowledge construction in a private Higher Education Institution. It is a research with qualitative approach, applied at Projeção College, Distrito Federal, to the members of the academic community involved in its Technology School. By the literature review and document analysis, it is expected to propose a model of knowledge construction for this institution and to assess how the School of Technology behaves in this scenario.

Keyword: Organizational communication; Knowledge management; Organizational learning; Knowledge construction.

Recebido em 19.03.2014 Aceito em 23.08.2015

\section{Introdução}

O conhecimento nas organizações tem assumido papel de protagonista e esse ato deve se repetir para as sociedades futuras. 0 conhecimento entrou em cena e relegou para segundo plano a ideia de 
que o valor das organizações estava em seus bens tangíveis. Como sugere Silva (2002), os recursos econômicos básicos passam a contar, além do capital, dos recursos naturais e da mão-de-obra, com o aporte dos conhecimentos necessários aos processos produtivos e de negócios.

A vantagem competitiva sustentável, que não seja tão elementar, pode ser um dos resultados da implantação de uma Gestão do Conhecimento coordenada (SILVA, 2004), pois é inerente às pessoas e suas subjetividades, e não está condicionada a recursos físicos, que podem ser copiados pelos concorrentes (QUINN et al., 1997) e ainda menos flexíveis frente às variáveis do ambiente (THOMKE; REINERTSEN, 1998).

A construção de conhecimento pode ser um resultado da própria necessidade de informação das pessoas envolvidas em uma determinada organização. Essa necessidade advém do comportamento informacional, em diferentes contextos, que "refere-se às atividades de busca, uso e transferência de informação nas quais uma pessoa se engaja quando identifica as próprias necessidades de informação" (GASQUE; COSTA, 2010, p. 22).

Quando o foco está nas Instituições de Educação Superior, a necessidade de informação está diretamente relacionada aos seus processos acadêmicos. O comportamento informacional de todos os envolvidos na comunidade acadêmica pode variar de acordo com o conhecimento do fluxo dos processos e como se dá a dinâmica de rastreabilidade da informação interna. A execução alinhada de tais processos pode subsidiar a Gestão de Conhecimento da instituição e favorecer a construção de conhecimento.

A falta de entendimento acerca dos processos e de como se estabelece uma comunicação eficaz pode impactar no aprendizado e na cultura organizacionais das Instituições de Educação Superior. A incerteza de como tais instituições trabalham com o conhecimento para 0 desenvolvimento de novos produtos, sejam bens ou serviços, novos processos e outras formas de arranjos organizacionais, pode reduzir a sua competitividade e posicionamento no mercado.

Diante do cenário mencionado, este artigo visa contribuir com um estudo que apresente como a relação entre Comunicação Organizacional, Gestão do Conhecimento, Aprendizagem Organizacional, e Cultura Organizacional pode corresponder um espaço de Construção de Conhecimento para uma Instituição de Educação Superior privada. Para lograr este objetivo, espera-se: (i) identificar os processos da Comunicação Organizacional, bem como seus aspectos epistemológicos e fundamentos teóricos; (ii) caracterizar a Gestão do Conhecimento, sob enfoque contemporâneo; (iii) relacionar vertentes teóricas de Aprendizagem Organizacional e seus elementos centrais; (iv) relacionar abordagens de Cultura Organizacional; e (v) propor um modelo conceitual com base na revisão de literatura e nos processos acadêmicos da Instituição de Educação Superior.

Segundo Morosini et al. (2011, p. 126), no contexto pós Lei de Diretrizes e Bases da Educação Nacional (LDB) de 1996, houve no Brasil 
um significativo movimento expansionista das Instituições de Educação Superior, sobretudo com a flexibilização das formas organizacionais de oferta da Educação Superior, "privilegiando a diversidade de formatos institucionais e modalidades acadêmicas e sua diversificação, repercutindo na questão da privatização do ensino". Logo, identificar, definir, organizar, controlar e maturar os processos internos são atividades vitais para uma Instituição de Educação Superior, principalmente as constituintes da rede privada de ensino.

A estrutura do artigo permite a identificação de três seções: (i) a revisão de literatura que incita o referencial proposto para o estudo, envolvendo Comunicação Organizacional, Gestão do Conhecimento, Aprendizagem Organizacional, e Cultura Organizacional; (ii) a abordagem e execução metodológica, que compreende as atividades de coleta e análise dos dados para a pesquisa; e (iii) apresentação dos resultados e correlação as teorias envolvidas no estudo.

\section{Comunicação Organizacional}

A comunicação é um dos fatores mais importantes nas organizações (KUNSCH, 2003; GIBSON et al., 1981). A Comunicação Organizacional possui muitas definições, dependendo do contexto sob o qual é avaliada e, segundo Medrano (2007, p. 39), pode ser definida como "um processo que ocorre, que tem lugar, entre os membros de uma coletividade social". Já Kunsch (2003) entende a Comunicação Organizacional como uma teoria que estuda como o fenômeno comunicacional se processa dentro das organizações, analisa o sistema, o funcionamento e o processo de mediação da comunicação entre a organização e seus públicos internos e externos, no âmbito da sociedade global. O domínio da comunicação, seja ela interna ou externa, é essencial para a sobrevivência da organização. O conhecimento dos fluxos e das interações entre os diversos níveis da organização pode auxiliar na organização de estruturas comunicacionais eficazes, mediadas por variados canais, inclusive por sistemas informatizados. O Quadro 1 apresenta a abordagem teórico-conceitual de Scroferneker (2006), sobre Comunicação Organizacional, que destaca autores e suas diferentes percepções.

\section{Quadro 1 - Diferentes abordagens de Comunicação Organizacional}

\begin{tabular}{c|l}
\hline AUTOR & \multicolumn{1}{c}{ DEFINIÇÃO COMUNICAÇÃO ORGANIZACIONAL } \\
\hline \hline \multirow{2}{*}{ HALL } & "examina a comunicação nas organizações considerando os fatores que afetam o envio, o \\
$(1984)$ & recebimento, a percepção e as interpretações dessas comunicações. A comunicação é um \\
& processo relacional - emissor/receptor - isto é, as relações sociais que se processam entre ambos, \\
& os envolvem, como seus efeitos recíprocos à medida que se comunicam”. \\
\hline \multirow{2}{*}{ KREPS } & "como um processo através do qual os membros da organização obtêm as informações \\
$(1990)$ & organizacional desempenha uma função de fonte de informação (data-gathering) para os \\
& membros da organização. A informação se constitui a variável intermediária que une a \\
\hline
\end{tabular}




\begin{tabular}{|c|c|}
\hline AUTOR & DEFINIÇÃO COMUNICAÇÃO ORGANIZACIONAL \\
\hline & " comunicação à organização". \\
\hline $\begin{array}{l}\text { GOLDHAB } \\
\text { ER (1991) }\end{array}$ & $\begin{array}{l}\text { "partindo da concepção que a organização é um sistema vivo e aberto conectado por um fluxo de } \\
\text { informações entre as pessoas que ocupam diferentes posições e representam distintos papéis, } \\
\text { define a comunicação organizacional como sendo o fluxo de mensagens processadas em uma } \\
\text { rede de relações interdependentes". }\end{array}$ \\
\hline $\begin{array}{l}\text { RIEL } \\
\text { (1995) }\end{array}$ & $\begin{array}{l}\text { "engloba relações públicas, estratégias organizacionais (public affairs), marketing corporativo, } \\
\text { propaganda corporativa, comunicação interna e externa, enfim um grupo heterogêneo de } \\
\text { atividades de comunicação, voltadas, fundamentalmente, para os públicos ou segmentos com os } \\
\text { quais a organização se relaciona e depende". }\end{array}$ \\
\hline $\begin{array}{c}\text { RESTREPO } \\
\text { J. (1995) }\end{array}$ & $\begin{array}{l}\text { "a comunicação nas organizações deve ser entendida de forma integral, permeando todas as ações } \\
\text { organizacionais, viabilizando de maneira permanente a construção de sua cultura e identidade, e } \\
\text { marcando um estilo próprio e suas formas de projetar-se exteriormente (a construção de sua } \\
\text { imagem)". }\end{array}$ \\
\hline
\end{tabular}

Fonte: Adaptado de Scroferneker (2006).

Para Curral e Chambel (2001), a definição de comunicação é "o processo pelo qual um grupo gera a informação". Medrano (2007) complementa que a Comunicação Organizacional refere-se, também, aos fluxos de dados - que são coadjuvantes, de algum modo - dos seus processos de comunicação e intercomunicação. A necessidade humana de se comunicar leva a comunicação organizacional a impulsos unicamente social. Segundo Tubbs e Moss (2003), a comunicação humana ocorre no contexto das organizações.

\subsection{Aspectos epistemológicos}

O ser humano pertence a grupos e organizações desde a sua origem. Do momento em que o ser humano se junta a outros para desenvolver-se é possível falar em organização. A Comunicação Organizacional compreende "frutos de sementes lançadas no período da Revolução Industrial do século passado, que ensejaria grandes e rápidas transformações em todo o mundo" (MEDRANO, 2007, p. 20). Ao longo da história existiram escolas de Comportamento Organizacional que podem ser sumarizadas em quatro teorias: (i) clássica; (ii) humanista; (iii) de sistemas; e (iv) das contingências, conforme destacado no Quadro 2. Os debates sobre os processos de comunicação nas organizações, historicamente vinculada ao domínio das empresas, segundo Deetz (2001), voltou-se nas últimas três décadas para o campo da Comunicação Organizacional, e as práticas de comunicação continuam como apoio às relações que as organizações estabelecem com grupos externos e internos.

Quadro 2 - A Comunicação Organizacional na história

\begin{tabular}{l|l|l|l}
\hline TEORIA CLÁSSICA & TEORIA HUMANISTA & TEORIA DE & TEORIA DA \\
\hline
\end{tabular}




\begin{tabular}{|c|c|c|c|}
\hline & & SISTEMAS & CONTINGÊNCIA \\
\hline $\begin{array}{l}\text { Max Weber, Frederick } \\
\text { W. Taylor, Henri Fayol }\end{array}$ & $\begin{array}{c}\text { Elton Mayo, Kurt Lewin, } \\
\text { Rensis Likert, Douglas } \\
\text { Mcgregos, Chris Argyris }\end{array}$ & $\begin{array}{c}\text { E. Trist, Daniel Katz, } \\
\text { Robert Kahn }\end{array}$ & $\begin{array}{c}\text { Joan Woodward, Tom } \\
\text { Buns, Stalker, Paul } \\
\text { Lawrence, Jay Lorsch }\end{array}$ \\
\hline $\begin{array}{l}\text { - Comunicação muito } \\
\text { formal. } \\
\text { - Preponderância } \\
\text { escrita. } \\
\text { - Vertical descendente. } \\
\text { - Muito regulada. } \\
\text { - Conteúdo básico de } \\
\text { normas e } \\
\text { procedimentos. } \\
\text { - Centralização das } \\
\text { decisões. } \\
\text { - Supervisão próxima e } \\
\text { controle. } \\
\text { - Não considera as } \\
\text { necessidades dos } \\
\text { empregados. } \\
\text { - Nível organizacional. }\end{array}$ & $\begin{array}{l}\text { - Comunicação formal e } \\
\text { informal. } \\
\text { - Oral e escrita. } \\
\text { - Horizontal, vertical e } \\
\text { ascendente, vertical e } \\
\text { descendente. } \\
\text { - Flexível. } \\
\text { - Conteúdo básico } \\
\text { grupal (padrões de } \\
\text { necessidades) e } \\
\text { interno. } \\
\text { - Alta descentralização } \\
\text { na tomada de decisão. } \\
\text { - Flexibilidade interna } \\
\text { sem considerar } \\
\text { elementos externos. } \\
\text { - Alta consideração das } \\
\text { necessidades dos } \\
\text { empregados. }\end{array}$ & $\begin{array}{l}\text { - Comunicação formal e } \\
\text { informal entre } \\
\text { sistemas e } \\
\text { subsistemas. } \\
\text { - Oral e escrita. } \\
\text { - Horizontal e vertical. } \\
\text { - Regulação variável. } \\
\text { - Conteúdo básico } \\
\text { organizacional interno } \\
\text { e externo. } \\
\text { - Descentralização } \\
\text { variável. } \\
\text { - Busca de equilíbrio } \\
\text { interno e externo. } \\
\text { - Importância da } \\
\text { retroalimentação. } \\
\text { - Consideração das } \\
\text { necessidades } \\
\text { individuais. } \\
\text { subsistemas e sistemas } \\
\text { sem ênfases na } \\
\text { e saída. }\end{array}$ & $\begin{array}{l}\text { - Comunicação básica } \\
\text { formal dentro e entre } \\
\text { sistemas. } \\
\text { - Oral e escrita. } \\
\text { - Horizontal e vertical, } \\
\text { interna e externa. } \\
\text { - Regulação variável } \\
\text { segundo demandas do } \\
\text { entrono (situacional). } \\
\text { - Conteúdo básico } \\
\text { organizacional e } \\
\text { externo. } \\
\text { - Descentralização } \\
\text { variável segundo as } \\
\text { demandas do contexto. } \\
\text { - Comunicação como } \\
\text { elemento integrador. } \\
\text { - Necessidades totais ou } \\
\text { parciais segundo } \\
\text { demanda do contexto. } \\
\text { demandarganizacional } \\
\text { - } \text { parcial, segundo } \\
\text { dema contexto. }\end{array}$ \\
\hline
\end{tabular}

Fonte: Adaptado de Medrano (2007).

O estudo da comunicação nas organizações ganhou especial destaque a partir dos anos 40.Sexton e Staudt (1959) publicaram uma revisão de literatura sobre a comunicação organizacional e encontraram 178 títulos, a maioria publicados entre 1945 e 1958. Simon (1955) destacou o processo de comunicação como essencial para a organização e Bavelas e Barret (1951) descreveram a comunicação como o processo básico das organizações, a partir do qual todas as outras funções derivam (CURRAL; CHAMBEL, 2001, p. 413).

De acordo com Scroferneker (2006, p. 48): 
Os estudos da comunicação organizacional são marcados, tomando como referência dois grandes períodos, de 19001970 e de 1970 até o presente momento. No período que se estende de 1900 a 1970, os diferentes conceitos e teorias desenvolvidos apoiaram-se fundamentalmente na Doutrina Retórica Tradicional, na Teoria das Relações Humanas e na Teoria da Gestão Organizacional. [...] A partir de então, as abordagens teóricas centraram-se na Teoria Moderna ou Empírica, na Teoria Naturalista e na Teoria Crítica.

A autora faz uma revisão de literatura, abarcando diversos autores que contextualizam a evolução das teorias sobre a comunicação organizacional, e em suma:

os recentes trabalhos de comunicação organizacional foram moldados pelo interesse na comunicação empresarial e industrial - dos anos 20 aos anos 50 - e pela influência da escola de relações humanas, dos anos 50 até meados de 1970. [...] Os anos 80 trazem uma '[...] reviravolta no conhecimento acadêmico da comunicação organizacional', o que não significou '[...] uma ruptura completa com o passado". É nesse contexto que novas correntes emergem, dentre elas, a teoria Naturalista e a teoria Crítica. [...] A teoria crítica surge no final dos anos 80. Alguns de seus pressupostos teóricos podem ser encontrados no materialismo dialético. A organização é vista sempre como uma arena de conflitos: um campo de batalha - o locus do conflito de classes. [...] a década de 90 caracterizou-se pela a emergência de uma série de teorias e propostas, que buscaram 'enxergar' as organizações e (re)interpretá-las. [...] Além da teoria crítica [destaca-se], com base em estudos realizados por Fernández Colado (2001), a teoria narrativa pósmoderna e a teoria da administração baseada em equipes como as propostas básicas que alimentaram a comunicação das organizações nessa década. [...] A teoria narrativa pós-moderna é composta por três narrativas fundamentais: a condição pós-moderna, a economia pastiche e o simulacro. [...] A teoria da administração baseada em equipes se caracteriza, essencialmente, pela comunicação multidirecional nas organizações. Assume destaque o papel dos líderes, identificados como responsáveis por gerar grupos de trabalhos fortes e coesos (SCROFERNEKER, 2006, p. 48). 


\subsection{Fundamentos teóricos}

Gibson et al. (1981) dá uma vertente da Administração quando se refere à Comunicação Organizacional. Para o autor, as funções administrativas básicas (planejar, organizar, controlar e dirigir) são operacionalizadas mediante a atividade de comunicação, ressaltando sua importância para o funcionamento das organizações.

A estrutura da organização deve propiciar a comunicação basicamente em três direções diferentes (GIBSON et al., 1981): (i) de cima para baixo, quando a emissão das mensagens parte dos indivíduos que estão em uma posição hierárquica superior, e normalmente são instruções ou determinações para alguma atividade; (ii) de baixo para cima, quando o emissor das mensagens está em um nível hierárquico inferior ao do receptor; e (iii) horizontalmente, que consiste na comunicação estabelecida entre os pares. Kunsch (2003), Curral e Chambel (2001), Tubbs e Moss (2003) corroboram com a abordagem de Gibson et al. (1981), quando consideram a existência dos três tipos de fluxos por meio do qual a comunicação pode ser feita na organização (ascendente, o descendente e o horizontal).

O homem é um ser social, portanto uma comunicação eficaz é essencial. A efetividade da comunicação pode ser influenciada pelos canais pela qual ela é mediada. Enquanto Curral e Chambel (2001) consideram que o canal mais efetivo dentro de uma organização, para que a comunicação de mensagens complexas, seja o encontro presencial por permitir o contato pessoal, resposta imediata, e para evitar eventuais problemas de comunicação, Quinn (1992) percebe a importância dos processos organizacionais à medida que as organizações aumentam seu conteúdo intelectual.

Medrano (2007) pontua as questões da responsabilidade social das organizações frente aos embates do mercado, apresentando assim a cidadania como um exercício fundamental das organizações. O autor ainda relaciona quatro perspectivas a serem consideradas na Comunicação Organizacional:

a)a perspectiva mecânica: percebe a Comunicação Organizacional como um processo no qual a mensagem passa por um canal de um ponto a outro;

a perspectiva psicológica: o modo como as características do indivíduo afetam sua comunicação;

b)a perspectiva interpretativa-simbólica: significados compartilhados e comportamento social;

c)a Perspectiva de interação de sistemas: concentra-se em comportamentos externos como as unidades fundamentais de análise. 
Medrano (2007) enfatiza que a Comunicação Organizacional integrada como uma filosofia que direciona a convergência entre diversas áreas, como as Relações Públicas (Comunicação Institucional), Comunicação Interna (Comunicação Administrativa) e o Marketing (Comunicação Mercadológica). O autor ainda indica as terminologias que são usadas indistintamente no Brasil para designar todo trabalho de comunicação estabelecido em ou por organizações: Comunicação Organizacional; Comunicação Empresarial; e Comunicação Corporativa.

Kunsch (2003) sistematiza os tipos de comunicação e influências primárias na transmissão de informações (Quadro 3), em função do nível de análise, item que será tratado a posteriori neste estudo.

Quadro 3 - Tipos de comunicação e influências primárias na transmissão de informações

\begin{tabular}{|c|c|c|}
\hline $\begin{array}{c}\text { CONTEXTO DA } \\
\text { COMUNICAÇÃOO }\end{array}$ & $\begin{array}{l}\text { TIPO DE COMUNICAÇÃO } \\
\text { (nível de análise) }\end{array}$ & $\begin{array}{c}\text { INFLUÊNCIAS PRIMÁRIAS } \\
\text { NA TRANSMISSÃO DE } \\
\text { INFORMAÇÕES } \\
\end{array}$ \\
\hline Independente da organização & - Interpessoal & $\begin{array}{l}\text { - Fenômenos cognitivos e papéis } \\
\text { e normas sociais }\end{array}$ \\
\hline Dentro da organização & $\begin{array}{l}\text { - Interpessoal } \\
\text { - Interunidades }\end{array}$ & $\begin{array}{l}\text { - Papéis e normas organizacionais } \\
\text { mais as normas sociais } \\
\text { aplicáveis. } \\
\text { - Relações interdepartamentais, } \\
\text { efeitos conjuntos das } \\
\text { informações trocadas. }\end{array}$ \\
\hline $\begin{array}{l}\text { Externo a uma organização } \\
\text { específica }\end{array}$ & $\begin{array}{l}\text { - Interorganizacional } \\
\text { - Organizacional ambiental }\end{array}$ & $\begin{array}{l}\text { - Relações entre as organizações. } \\
\text { - Componentes ambientais }\end{array}$ \\
\hline
\end{tabular}

Fonte: Adaptado de Kunsch (2003).

Sob as percepções de Iasbeck (1999) é importante levar em consideração a comunicação informal como parte da Cultura Organizacional, pois esta representa subjetividades que estão ocultas no discurso dos indivíduos, principalmente quando a Comunicação Organizacional é percebida como um processo coletivo de produção de sentidos e não apenas um sistema de informações.

\subsection{Processo de Comunicação Organizacional}

O modelo de comunicação de Gibson et al. (1981) apresenta o processo que envolve a transmissão da informação (mensagem), pelo que o autor considera como comunicador, por algum canal de comunicação até que chegue ao receptor. O resultado desta comunicação pode ser avaliado por feedback do receptor ao comunicador, que, por sua vez, pode reiniciar o processo de comunicação (Figura 1). 
Figura 1 - Modelo de comunicação de Gibson et al.

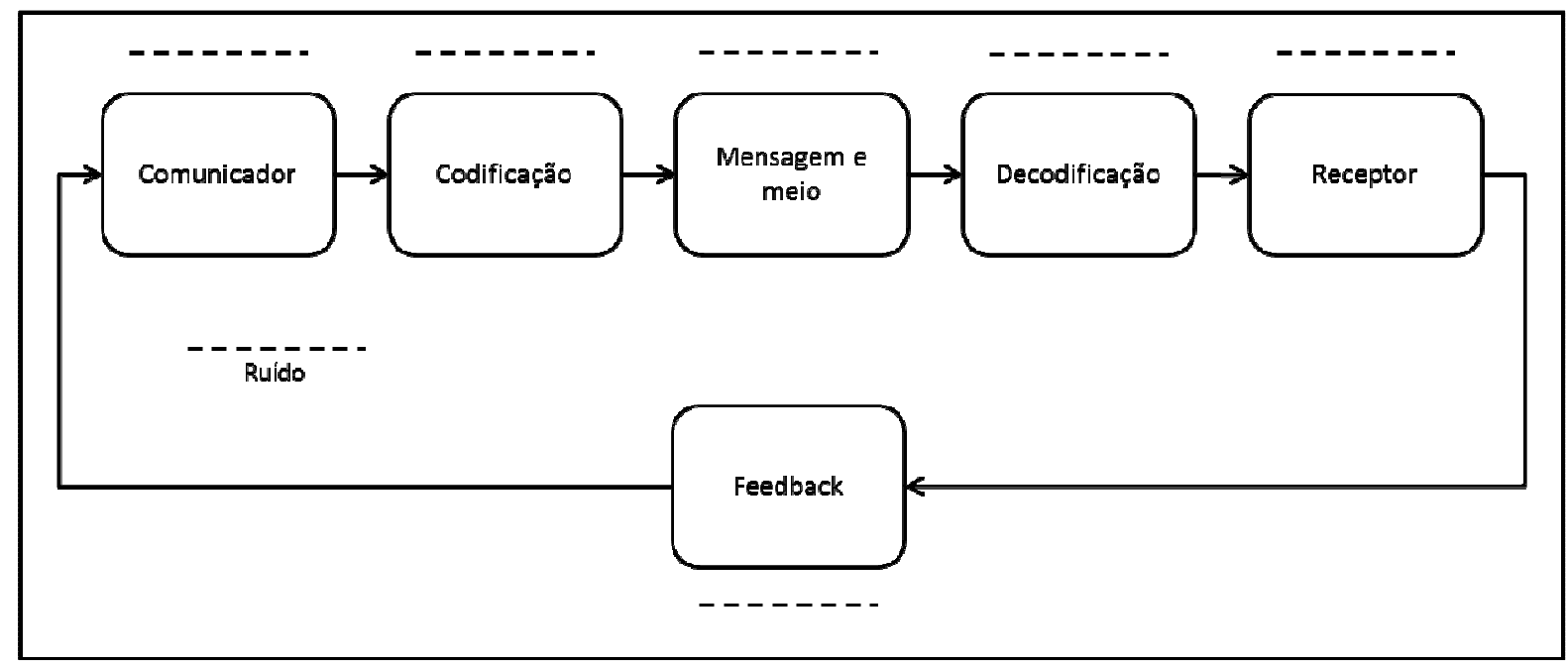

Fonte: Adaptado de Gibson et al. (1981).

a)o comunicador: é a pessoa com ideias, intenções, informação e propósito de comunicação;

b)a codificação: existindo um comunicador, é preciso existir um canal de codificação que traduza as ideias do comunicador;

c)a mensagem: é o resultado do processo de codificação. $O$ comunicador a expressa de maneira verbal ou não-verbal. A mensagem será o que o sujeito espera comunicar ao receptor;

d)o meio: é o suporte da mensagem. As organizações se comunicam de várias maneiras: face a face, por telefone, reunião, memorando, computadores;

e)o decodificador-receptor: o processo de comunicação para ser bem entendido precisa ser compreendido pelo receptor. Os receptores interpretam (decodificam) a mensagem através de experiências e estruturas de referências anteriores. Quanto mais a mensagem decodificada representar aquilo que se foi pretendido pelo comunicador, melhor será a comunicação;

f)o feedback: é necessário o processo de feedback para a comunicação, pois evita as distorções que poderão ocorrer na comunicação entre mensagem pretendida e proposta;

g)o ruído: é o conjunto de todos os fatores que distorcem a mensagem pretendida pelo comunicador.

No que se refere especificamente aos ruídos no processo de comunicação, Curral e Chambel (2001) relacionam as seguintes categorias:

a)problemas semânticos: problemas decorrentes da complexidade da mensagem do emissor para o receptor; 
b)efeito do estatuto: o nível de estatuto determina a autoridade e a tendência de quem emite mais, ou menos, mensagens;

c)ausência de feedback: não há certificação da efetividade da comunicação;

d)distrações: eventos externos que interferem no processo de comunicação;

e)percepção do outro: cada indivíduo tem uma percepção diferente do mundo, de acordo com as suas subjetividades, que pode influenciar na interpretação da informação.

Continuando a ideia de caracterização do processo de Comunicação Organizacional, é interessante referenciar o "modelo mecanicista" que, segundo Kunsch (2003), dominou a Comunicação Organizacional nas décadas de 1960, 1970 e 1980, e continua em pleno século XXI em algumas organizações. Tal modelo...

[...] considera e avalia a comunicação sob o prisma funcionalista e da eficácia organizacional [...]. Preocupa-se com as estruturas formais e não formais de comunicação e com a prática em função do resultado, deixando de lado as análises do contexto social, político, econômico, tecnológico e organizacional (KUNSCH, 2003, p. 72).

Kunsh (2003, p. 73) ressalta que as organizações precisam avaliar os fatores intrínsecos e extrínsecos do que constituem um aglomerado de pessoas que trabalham coletivamente para atingir metas, cada uma com a sua cultura, universo cognitivo, maneira de pensar, sob pressão dos ambientes internos e externos, além das barreiras presentes no processo de comunicação, pontuando o lado humano das organizações. É importante compreender a complexidade do ato comunicativo na gestão do processo de comunicação, relevando "as barreiras, os níveis de análise, as redes, os fluxos, os meios e as diversas modalidades comunicacionais existentes":

a)barreiras: (i) pessoais, relevando as idiossincrasias de cada indivíduo, bem como seus valores e emoções; (ii) administrativas, como a forma com que as organizações atuam e processam suas informações; (iii) excesso de informação, como consequência da falta de seleção de prioridades; (iv) comunicação incompleta e parcial, com informações fragmentadas, distorcidas ou sonegadas; e (v) outras barreiras como audição seletiva, juízo de valor, falta de credibilidade da fonte de informação, semântica, linguagem intergrupal, diferença de status, entre outras; 
b)níveis de análise da comunicação: (i) intrapessoal, sobre o que se passa dentro do indivíduo; (ii) interpessoal, sobre o que se passa entre indivíduos; (iii) organizacional, sobre as relações internas da organização com o ambiente externo; e (iv) tecnológico, sobre a utilização de tecnologias para processar e distribuir informações;

c)redes: (i) formais, que representam o conjunto de canais e meios de comunicação estabelecidos de forma consciente e deliberada, traduzidos em normas e estratégias da organização; (ii) informação, baseado nas relações sociais, que pode ser a forma mais rápida de atender as demandas mais urgentes e instáveis;

d)fluxos comunicativos: tratam de hierarquia com comunicações verticais (descendentes e ascendentes) e horizontais (ou laterais);

e)meios de comunicação: podem ser orais, diretos e indiretos, escritos, pictográficos, simbólicos, escrito-pictográficos, audiovisuais, telemáticos e presencial pessoal.

\section{Gestão do conhecimento}

A atividade de Gestão do Conhecimento pode ser entendida como o processo pelo qual uma organização, tanto do ponto de vista de seus colaboradores, quanto resultantes da aprendizagem organizacional, mapeia e apropria conhecimentos dos trabalhadores, dissemina internamente e os compartilha (primeira geração); apropria, aprende, protege e transforma conhecimentos tácitos em explícitos e vice versa (segunda geração); e (terceira geração) e gera novos ativos por meio da pesquisa e desenvolvimento ou outros meios. A comunicação de qualidade, tanto no ambiente interno, quanto externo às organizações, pode melhorar os processos de Gestão do Conhecimento, no sentido de produzir inovações e lograr melhores desempenhos organizacionais. Choo (2000) considera o fator conhecimento cultural, com base nas crenças, valores e competências, sob enfoque dos aspectos humanos, para constituir os elementos da Gestão do Conhecimento, agregado aos conhecimentos tácitos e explícitos.

A Gestão do Conhecimento envolve a gestão dos processos pelos quais as organizações, de forma consciente e sistemática, se apropriam e criam conhecimentos coletivos e individuais para melhoria de competitividade no cumprimento de suas missões ou realização de negócios. Segundo Silva (2004), nos anos 80, a questão da Gestão do Conhecimento tornou-se mais presente com as propostas relacionadas à sociedade do conhecimento, à aprendizagem organizacional, à conexão com inteligência competitiva e introdução de inovações, bem como ao desenvolvimento das competências essenciais e a gestão estratégica ou 
de dinâmica complexa entre o processo decisório, competências e meios (ROCHA NETO; CARNEIRO, 2007).

Em sua revisão da literatura, Rica (2003) aponta que a gestão do conhecimento é a combinação de sinergias entre dados, informação, sistemas de informação, e a capacidade criativa e inovadora de seres humanos. Esta é uma visão estratégica da Gestão do Conhecimento que considera a sinergia entre o tecnológico e o humano, baseada na distinção entre o old world of business e o new world of business.

Desde o olhar do Gutiérrez (2006), a Gestão do Conhecimento pode ser entendida como sendo a disciplina que se encarrega de projetar e implementar um sistema cujo objetivo é identificar, captar e compartilhar sistematicamente o conhecimento contido em uma organização, de modo tal que possa ser convertido em valor para a mesma. No caso de Bouthillier e Shearer (2002) a Gestão do Conhecimento, na prática, significa facilitar o intercâmbio de conhecimento tácito.

O interesse em relação à Gestão do Conhecimento tem-se refletido na variedade de conceitos associados (Inteligência, Informação, Gestão, Conhecimento, Ativos Intangíveis, Competências, Inovação, Aprendizagem Organizacional, entre outros). A maior dificuldade tem sido a limitação das definições e das terminologias encontradas nos dicionários, que tem levado inclusive à negação da possibilidade de gestão do conhecimento ou a entendê-la como mais um modismo (WILSON, 2002).

De acordo com Nonaka e Takeuchi (1997), o conhecimento está relacionado à ação, isto é, o conhecimento visa a algum fim. A Gestão do Conhecimento deve procurar estimular a aplicação de conhecimentos nas suas atividades estratégicas. A capacidade de compartilhar e criar conhecimento promovendo a aprendizagem organizacional, e prover suporte à colaboração permite transformar informação em vantagem competitiva para as organizações em seus ambientes de concorrência ou para cumprimento de suas missões. Nesse sentido, há uma constante preocupação em transformar dados em informação e conhecimento de modo a promover um entendimento ou consciência geral de uma instituição, bem como dispor o resultado deste processo aos gestores, permitindo a gestão da inteligência organizacional.

Para as organizações do conhecimento, há novos tempos onde a velocidade das mudanças se torna a cada dia maior, gerando, por sua vez, a necessidade de renovação das organizações. As novas abordagens e teorias organizacionais surgem para dar suporte e indicar caminhos de sobrevivência. No dizer de Flores (1997) as organizações hoje se defrontam com a necessidade de mais inovação em todos os níveis hierárquicos. A velocidade com se introduzem novos produtos e serviços, especialmente nas indústrias de alta tecnologia, cresce vertiginosamente. Hoje em dia, uma companhia deve inovar para competir. Necessitamos de gente que improvise e responda de forma flexível, criando novas ofertas que os clientes sequer imaginam.

Novas e maiores exigências que poderão ser atendidas com um elemento que se coloca entre os fatores de produção como, talvez, o de 
maior valor. Já não se pode contar apenas com terra, capital e trabalho como fontes geradoras de riqueza. O novo elemento é o conhecimento.

É relevante considerar o papel das Tecnologias de Informação e Comunicação nos processos de Gestão do Conhecimento. Em um ambiente organizacional, a valorização e o estímulo ao conhecimento podem garantir o sucesso no mercado. Esse fato pode representar o desejo de muitas organizações atuais que buscam compreender os conhecimentos existentes e gerados em seu âmbito para uma atualização que suporte as constantes mudanças geradas, sobretudo, pelas TIC.

Verifica-se também a importância da socialização do conhecimento como conversão de parte do conhecimento tácito de uma pessoa no conhecimento tácito de outra pessoa, através do compartilhamento de experiências, do diálogo, da observação, da imitação e da prática, por exemplo. Outro ponto importante e que pode agregar valor à organização é a combinação do conhecimento explícito dos colaboradores com o conhecimento explícito da organização. Isso pode gerar um conhecimento sistêmico por meio da classificação e sumarização do conhecimento e do processamento de diferentes conhecimentos explícitos.

As organizações que trabalham com gestão do conhecimento podem oferecer contribuições significativas para a disseminação e socialização do conhecimento, como uma postura de transformação organizacional em termos de compartilhamento de conhecimento e dos processos de sua construção coletiva orientada para se tornarem "eternas aprendizes".

\subsection{Abordagem contemporânea}

A Gestão do Conhecimento tem considerado que conhecimentos podem ser expressos de três formas distintas e complementares, tanto presente nas mentes das pessoas (tácitos), quanto materializados em registros diversos (livros, relatórios, softwares, documentos diversos (explícitos), ou ainda em processo de criação como resultados parciais de pesquisa e desenvolvimento (projetos, protocolos e relatórios)).

Aplicações da tecnologia da informação podem facilitar o acesso, a mediação e a renovação dos conhecimentos. O enfoque de criação de conhecimento para gestão organizacional está na disposição das pessoas para trocar experiências e compartilhar com outras. Há possibilidades de conversão entre as distintas expressões de conhecimento: (i) socialização (tácito de um indivíduo para outros); (ii) explicitação, materializando conhecimentos tácitos em diferentes documentos, combinação (conhecimento explícito de um indivíduo para o grupo); (iii) apropriação, identificando as experiências dos colaboradores para aprendizagem e aplicação nas organizações; (iv) criação de conhecimento pode ocorrer em ambientes de conversão entre as suas distintas formas de expressão (SILVA, 2002).

Nonaka e Takeuchi (1997) identificaram distintos processos de conversão entre conhecimento tácito e explícito: o processo de explicitar ou transformar conhecimento tácito em explícito; apropriar como o processo inverso; combinar, mediante interação entre conhecimentos 
explícitos e implícitos para geração de novos conhecimentos; e socializar também por interação das pessoas e transmissão de conhecimentos tácitos.

Gutiérrez (2006) afirma que o principal desafio da Gestão do Conhecimento é converter todo conhecimento tácito, explícito, individual, interno e externo existente na organização, sistematicamente, em conhecimento organizacional ou corporativo. Este, ao ser acessível e compartilhado, permitirá o aumento do conhecimento individual de todos os seus membros, propiciando uma melhor contribuição desses indivíduos a atingir os objetivos da própria organização.

O conhecimento tem sido foco de trabalho interdisciplinar e tem se apresentado como uma questão central para todas as sociedades. A aprendizagem pode ser resultado de mudanças do comportamento observável. O conhecimento pode ser tratado como resultado da comunicação e da aprendizagem e produto de um processo de reelaboração construtiva do conhecimento socialmente compartilhado, sob enfoque da Gestão do Conhecimento.

Segundo Rocha Neto e Carneiro (2007), a aprendizagem pode se dar em três níveis: (i) o mais simples, quando apenas aperfeiçoa o fazer, sem mudanças nos métodos e no olhar sobre a realidade observada; (i) a adoção de novos métodos de fazer o que se fazia antes no sentido de aperfeiçoá-lo; e (iii) o mais profundo e radical, quando envolve mudanças no olhar e dos pontos de vista para observar a realidade, o que pode ensejar mudanças nos métodos e no fazer (o que, por que, e como). Assim, os processos de Gestão do Conhecimento se relacionam com a comunicação e com a Aprendizagem Organizacional na medida em que o compartilhamento e a geração de conhecimentos novos envolvam mudanças nas formas de olhar a realidade, nos métodos de trabalho e no aperfeiçoamento de práticas já adotadas.

\subsection{Processos envolvidos na Gestão do Conhecimento}

Considerando que o conceito dos termos Gestão da Informação e Gestão do Conhecimento pode ser passível de mudanças, Choo (2000) propõe um modelo para Gestão da Informação com 4 fases e cada uma requer o planejamento, a organização, a coordenação e o controle do número de atividades sustentadas pelas tecnologia da informação: (i) identificação das necessidades informacionais; (ii) aquisição de informação; (iii) organização e armazenamento da informação; e (iv) distribuição e uso da informação. Por outro lado, Nonaka e Takeuchi (1997) descrevem os quatro processos para conversão do conhecimento: (i) socialização; (ii) externalização; (iii) combinação; e (iv) internalização. Esse modelo foca em como o conhecimento pode ser criado através do compartilhamento organizacional e sua utilização é identificada e avaliada em duas atividades chave da gestão de conhecimento: (i) geração de conhecimento envolve a criação de novas ideias e novos padrões; (ii) codificação de conhecimento e tranferência de conhecimento assegurando trocas de conhecimento entre indivíduos e departamentos. A Figura 2 
apresenta o modelo com as atividades envolvidas no fluxo do conhecimento organizacional, segundo Bouthilier e Shearer (2002).

Figura 2 - Fluxo do Conhecimento Organizacional

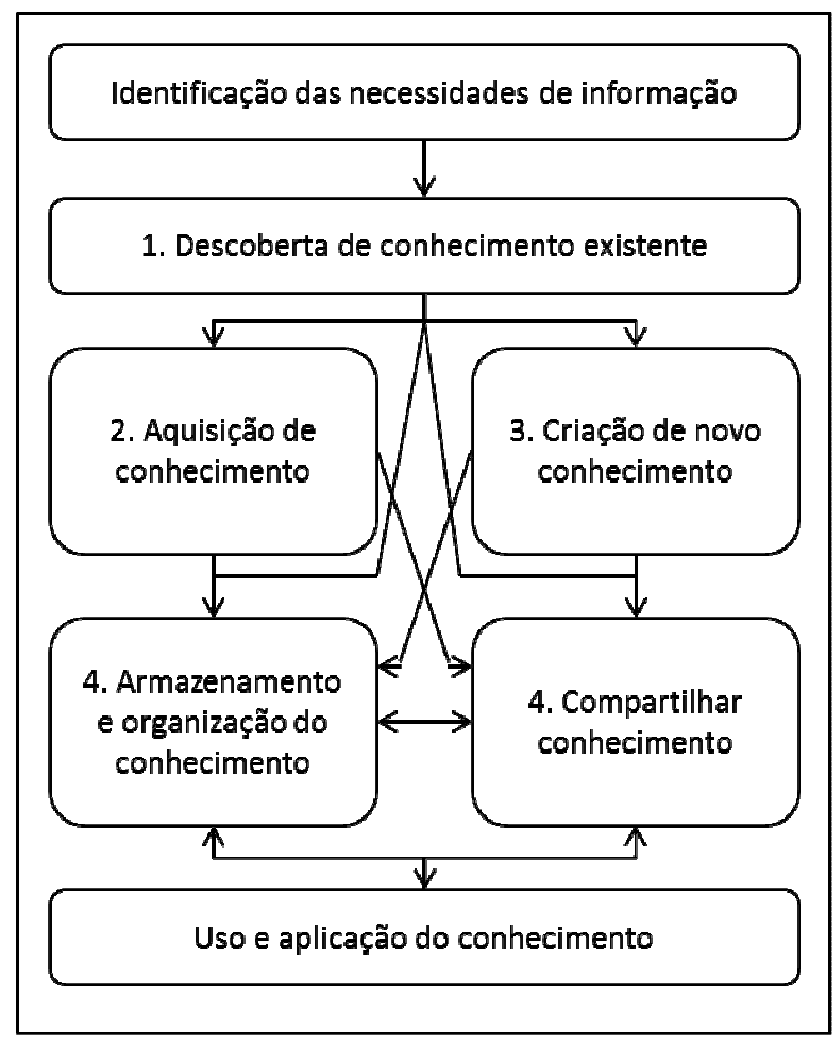

Fonte: Adaptada de Bouthilier e Shearer(2002).

\section{Aprendizagem organizacional}

A Aprendizagem Organizacional é abordada por Argyris (1995) e Senge (1995) como organizações que aprendem. As organizações que aprendem são instituições nas quais as pessoas se voltam para a aprendizagem coletiva, o que requer o comprometimento com resultados que sejam motivadores (SENGE, 1995). No que se refere à Aprendizagem Organizacional, Senge (1995) sugere as cinco disciplinas básicas do aprendizado: (i) domínio pessoal; (ii) visão compartilhada; (iii) modelos mentais; (iv) aprendizado em equipe; e (v) pensamento sistêmico. Ainda segundo o autor, é necessária uma perspectiva de liderança diferente da tradicional, com projeção de processos de aprendizagem, abertura e aceitação de outras visões que seu grupo possa ter, de modo a compartilhar a realidade da organização e propiciar a aprendizagem coletiva.

Argyris representa a Aprendizagem Organizacional a partir da teoria da ação, que envolve os componentes: estratégias de ação, valores que orientam as escolhas, e os pressupostos. O modelo de Argyris (1995) possui dois segmentos: (i) o proclamado, adoção consciente e que possui justificativas; e (ii) a aplicada, implícita nas estratégias de ação. Nesse sentido, a Aprendizagem Organizacional pode envolver a identificação e a 
correção do erro pelo circuito único - permitindo a alcance dos objetivos da organização - e pelo circuito duplo - permitindo visão nova dos objetivos, políticas e normas da organização.

Guimarães (2004), que sugere que o conceito de organização que aprende, demonstra a aplicabilidade em organizações em que as relações interpessoais entre os membros organizacionais são saudáveis, com a comunicação ampla e aberta, onde a inovação e a mudança são incentivadas e aceitas, e onde as pessoas percebem a interdependência entre o seu trabalho e o das demais. Esse conhecimento permite que a organização possa avançar e evoluir, para que com isso o sucesso individual contribua para eficiência e a eficácia organizacional.

Segundo Freitas e Brandão (2005) a aprendizagem significaria, então, o processo pelo qual se adquire a competência, enquanto o desempenho da pessoa no trabalho representaria uma expressão de suas competências, uma manifestação daquilo que ele aprendeu ao longo de suas vidas. Para Bastos et al. (2004), a aprendizagem organizacional constitui um processo amplo e complexo relacionado a uma abordagem cognitivista e fatores intra e interpisíquicos, e envolve uma mudança comportamental e atitudinal que envolve os planos afetivo, motor e cognitivo.

A Aprendizagem Organizacional envolve e por sua vez é envolvida por estratégias organizacionais, de modo a subsidiar a gestão e proporcionar mudanças estruturais e de produtividade, relacionando capacidades de renovação contínua a partir de: (i) incentivo ao aprendizado entre toda a equipe; (ii) cultura transcendente de aprendizagem; (iii) desenvolvimento de recursos humanos como política estratégica; e (iv) contínua busca por transformação organizacional.

\subsection{Elementos centrais da Aprendizagem Organizacional}

A aprendizagem a nível organizacional pode ser maior que a aprendizagem individual, porém não se estabelece sem ela. Nonaka e Takeuchi (1997) consideram que a mediação da aprendizagem individual para o nível organizacional depende de quatro formas de tratamento e conversão dos conhecimentos tácito e explícito: (i) socialização, conversão do conhecimento tácito para tácito; (ii) externalização, conversão do conhecimento tácito para explícito; (iii) combinação, conversão do conhecimento explícito para explícito; e (iv) internalização, conversão do conhecimento explícito em tácito. Schein (1985) agrega a Cultura Organizacional como elemento que favorece a Aprendizagem Organizacional, uma vez que se desenvolve em grupo por meio do compartilhamento de um conjunto de crenças, valores, símbolos e normas.

No contexto interorganizacional, alianças, fusões e aquisições se traduzem nasestratégias mais comuns utilizadas no compartilhamento e aquisição de novos conhecimentos.Sendo assim, percebe-se que as organizações optam pela busca de novos conhecimentosquando pressionadas pelas forças ambientais. Diante disso Child et al. (2005) 
afirmam queentre as motivações que levam uma organização a interagir com outras organizações está anecessidade de adquirir novas competências que viabilizem inovações de reconhecido valoreconômico no mercado.

No que se refere aos aspectos relevantes da Aprendizagem Organizacional, é possível relacionar os seguintes níveis:

a)aprendizagem organizacional sob nível de análise individual: "crescimento deinsightse de reestruturações bem-sucedidas de problemas organizacionais,provenientes de indivíduos que exercem papéis decisivos na estrutura e nos resultadosda organização".

b)aprendizagem organizacional sob nível de análise grupal: "aquisição, sustentação emudança de significados intersubjetivos através da expressão e transmissão de açõescoletivasde grupo" (COOK; YANOW, 1993).

c)aprendizagem organizacional sob nível de análise organizacional: processo pelo qual a base do conhecimento organizacional é construída e desenvolvida (SHRIVASTAVA, 1983). "codificação de inferências oriundas da história daorganização que se manifestam por meio de rotinas que guiam o comportamento"; "mudança no comportamento organizacional"; "a capacidade, conjunto de processos internos que mantêm ou melhoram o desempenho baseado na experiência, cuja operacionalização envolve a aquisição, a disseminação e a utilização do conhecimento" (DIBELLA et al., 1996, p. 365).

Pode haver aprendizagem organizacional em três circunstâncias: (i) quando a mudançaacontece em nível do grupo ou sistema; (ii) quando for constatada a mudança noconhecimento e valores coletivos; (iii) quando forem observadas mudanças nos padrõescomportamentais e normativos coletivamente partilhados. No que se refere às suasperspectivas, a aprendizagem organizacional relaciona (SHRIVASTAVA, 1983): adaptação; (ii) compartilhamento de pressupostos; (iii) institucionalização da experiência; (iv) desenvolvimento de base de conhecimento.

Sob o ponto de vista cognitivo/comportamental, organizações que aprendem são capazes deadquirir, criar, produzir novos insights, transferir conhecimentos e modificar ocomportamento de seus membros (GARVIN, 1993).Assim, a Aprendizagem Organizacional, como fator que favorece a Gestão doConhecimento, permite uma abordagem multidisciplinar e interdisciplinar envolvendo áreasde tratamento humano e de negócios, e com forte relação social dependendo do ambiente emque estes critérios estão presentes. 


\section{Cultura Organizacional}

A Cultura Organizacional pode ser entendida como um conjunto de normas e valores organizacionais e individuais que direcionam a conduta da organização. Os valores organizacionais dão suporte à manutenção da missão e da visão da organização. Os valores individuais caracterizam a personalidade individual adaptada ao ambiente organizacional e constituem atributos, crenças e desejos. Os valores da organização podem ser implícitos ou explícitos e definem questões éticas aceitáveis. Barichello et al. (2002) aponta que a cultura organizacional é um conjunto de valores implícitos que ajudam as pessoas na organização a entender quais ações são consideradas aceitáveis e quais são consideradas inaceitáveis, e que "permite entender como uma organização funciona, como são encarados os problemas, porque as pessoas agem de tal forma e respondem daquela maneira aos obstáculos que encontram".

A comunicação é o cerne da cultura. Segundo Schein (1985), fundamentalmente constituída de um sistema de crenças, valores e pressupostos básicos dos fundadores, que, com o passar do tempo, vão sendo aperfeiçoados e disseminados na organização por meio de diversos mecanismos, tais como: o que os líderes atribuem importância, tentando medir e controlar; como os líderes reagem a eventos críticos, carregados de emoção, e a crises organizacionais; modelagem de papéis e instruções intencionais; critérios para a concessão de recompensas e atribuição de status; critérios utilizados para recrutamento, seleção, promoção, aposentadoria e exclusão; desenho e estrutura da organização; sistemas e procedimentos organizacionais; disposição do espaço físico, fachadas e instalações; histórias, lendas, mitos e símbolos; e declarações formais da filosofia organizacional e seus credos.

As abordagens utilizadas no estudo do tópico apresentam indício de realidades organizacionais estruturadas por um conjunto de normas, diretrizes, crenças, valores e rituais, que estão fortemente relacionadas à Comunicação Organizacional, responsável pela criação, transmissão e formalização, de forma simbólica, do conhecimento da organização. Segundo Schein (1985), a cultura pode ser algo que a organização tem ou algo que a organização é. Assim, a organização pode ter normas, diagnósticos, missão e visão, ou pode ser um fenômeno social, com enfoque individual e coletivo, embasado em correntes cognitivista, estruturalista e simbólica.

\subsection{As relações da Cultura Organizacional}

A Cultura Organizacional pode estar presente nos processos de Comunicação Organizacional. Isso significa que as inferências pessoais, que constituem valores (IASBECK, 1999), podem interferir na efetividade do fluxo de comunicação. Tal concepção pode impactar nos processos de Aprendizagem Organizacional (SILVA, 2002), e consequentemente na Gestão do Conhecimento. Barichello et al. (2002, p. 2-3) apontam a relação entre comunicação e cultura, sendo que "a comunicação faz parte 
do processo cultural de uma organização e, desse modo, as formas como essa comunicação é, estrategicamente, utilizada e compreendida são processos constitutivos da sua cultura".

Conforme percepções de Silva (2001), os limites entre a Cultura Organizacional e a Aprendizagem Organizacional estão nos espaços de criação, transmissão e perpetuação da Cultura Organizacional e ainda explora tais limites como:

a)características organizacionais que inibem a aprendizagem;

b)pressupostos de cultura genuína de aprendizagem;

c)orientações baseadas em Cultura Organizacional inovadora;

d)ambiente de segurança psicológica a favor do estabelecimento da cultura de aprendizagem;

e)cultura organizacional que motive produção de cultura de aprendizagem.

No que se refere às interseções entre Cultura Organizacional e Aprendizagem Organizacional, seus conceitos são vistos como indissociáveis, uma vez que as pessoas aprendem dentro de contextos culturais decisivos na própria natureza do que é aprendido (COOK; YANOW, 1993).

\section{Proposta de um modelo conceitual de Construção de Conhecimento}

Considerando os conceitos e elementos levantados na revisão de literatura deste estudo, no contexto das organizações que mantêm processos bem definidos e gerenciáveis, é possível considerar a Cultura Organizacional como base que influencia e direciona as ações de uma organização, definindo suas diretrizes, procedimentos, normas, condutas, valores, objetivos, e impacta nos aspectos morais, éticos e profissionais dos colaboradores. A Cultura Organizacional pode nortear a Comunicação Organizacional, a Gestão do Conhecimento e a Aprendizagem Organizacional, em um ciclo dinâmico e não isolado que pode favorecer o estabelecimento de espaços de Construção de Conhecimento, estruturados por normas, valores organizacionais e individuais, crenças e desejos, sejam implícitos e/ou explícitos.

Existem características comuns entre a Cultura e Comunicação Organizacional que definem o estilo da organização, exprimindo a sua identidade. A formalidade e a informalidade, por exemplo, para a Comunicação Organizacional, têm a sua importância e ambas impactam na comunicação estratégica. Barichello et al. (2002) consideram que observar atentamente as subjetividades e interpretações das informações mediadas pelos colaboradores é uma ação estratégica para a organização, pois trata-se de um processo coletivo de produção de sentidos, vivo e em construção, e não apenas um sistema de informações formal, estático, e descrito em normas. 
Figura 3 - Elementos dos espaços de Construção de Conhecimento nas organizações

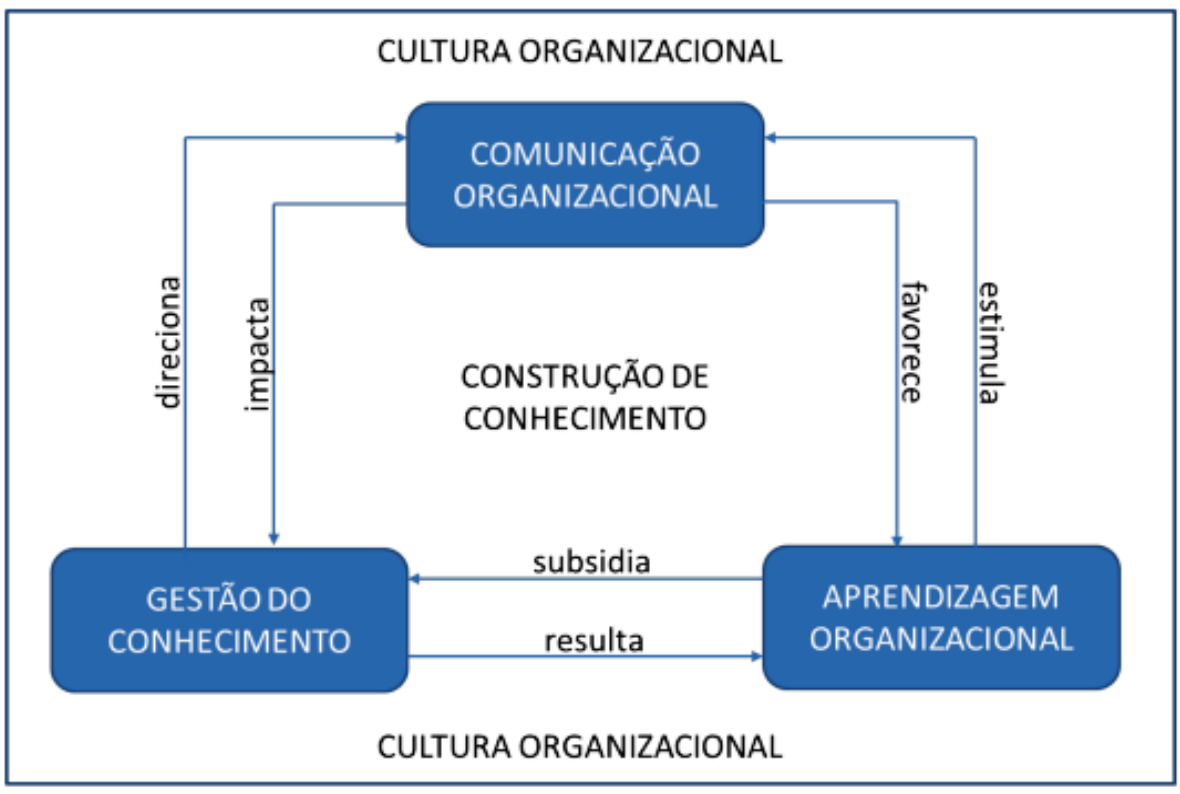

Fonte: Autores.

A Figura 3 apresenta a relação onde, ainda sob influência da Cultura Organizacional, o constructo da Comunicação Organizacional - que envolve processos, canais de comunicação, mediação, tecnologia, recepção, emissão, ruídos, símbolos, códigos, e mensagens - favorece a Aprendizagem Organizacional que por sua vez subsidia a Gestão do Conhecimento com mapeamento de processos, modelos mentais, trabalho em equipe, objetivo estratégico, pensamento sistêmico, tecnologias, resultados, compartilhamento e comunicação. A Gestão do Conhecimento leva em conta as trocas formais e informais de informação, apropriação, compartilhamento, participação e colaboração, e pode direcionar a Comunicação Organizacional, sobretudo, com os sistemas de informações, tecnologias e memórias. Quando a ênfase está na própria nos canais e processos de comunicação, criação, inovação, pesquisa e desenvolvimento, a Gestão do Conhecimento pode resultar em Aprendizagem Organizacional, constructo que estimula a Comunicação Organizacional. Assim, a relação entre os constructos Comunicação Organizacional, Aprendizagem Organizacinal e Gestão do Conhecimento, influenciados pela Cultura Organizacional, podem resultar em espaços de Construção de Conhecimento, que, segundo Kanuka e Anderson (1998) dependem do conhecimento acumulado, das experiências vivenciadas, interação e integração de ambientes. 


\section{Metodologia}

Para lograr o objetivo proposto, o estudo adota uma abordagem qualitativa e qualitativa, pois embora exista a relação dinâmica entre o mundo real e o sujeito, há tradução de opiniões e informações em números (SILVA, 2005). A metodologia envolve revisão de literatura e pesquisa descritiva "das características de determinada população ou fenômeno ou o estabelecimento de relações entre variáveis" (MARTINS, 1994, p. 28). O ambiente de estudo é a Faculdade Projeção, Instituição de Educação Superior privada renomada no âmbito do Distrito Federal, cuja missão é "promover a formação e desenvolvimento dos novos profissionais, incentivando o aprendizado contínuo, alicerçado na investigação científica e tecnológica, desenvolvendo a capacidade empreendedora e habilidades necessárias para serem bem sucedidos em uma sociedade de constantes mudanças, tendo como referenciais os valores éticos, a responsabilidade social e o compromisso com a qualidade na prestação de serviços".

O universo pesquisado, de caráter exploratório, é formado pelas unidades de informação da Faculdade Projeção (Central de Atendimento ao Aluno, Central de Atendimento Financeiro, Núcleo de Apoio Psicopedagógico ao Estudante (NAPES), Secretaria Acadêmica, Coordenação dos cursos de Tecnologia da Informação e Comunicação (TIC), Biblioteca, Central de Processo Seletivo, Direção de Escola, Direção de Unidade).

Os sujeitos do estudo são os membros da comunidade acadêmica diretamente envolvidos com os processos estabelecidos para a Escola de Tecnologia da Faculdade Projeção, Brasília - DF. A escolha por esse grupo

A coleta de dados é apoiada pela utilização do instrumento de pesquisa questionário, com questões fechadas e abertas, da mais abrangente para a mais específica, considerando o modelo proposto para o estudo. Primeiramente, há a elaboração de um questionário piloto, oriundo da revisão de literatura, e, então, sua associação ao resultado da pesquisa documental dos manuais, regulamentos, normas e resoluções, para chegar à sua versão final. O instrumento de coleta de dados deve ser disponibilizado eletronicamente, via Internet, com o escopo de survey online. As questões são classificadas em 5 grupos: (i) Comunicação Organizacional [COMORG]; (ii) Cultura Organizacional [CULTORG]; (iii) Aprendizagem Organizacional [APRORG]; (iv) Gestão do Conhecimento [GESCON]; e (v) Informações Gerais [INFGER], baseadas no modelo proposto para o estudo.

\section{Avaliação dos espaços de Construção de Conhecimento nos cursos de tecnologia FAPRO-P7}

A pesquisa foi realizada com colaboradores do Grupo Projeção que trabalham em centrais, setores, e diretorias que mantêm vínculo direto com as coordenações de cursos da Escola de Tecnologia, conforme escopo do estudo. Houve participação dos colaboradores das unidades Ceilândia, 
Guará, Sobradinho e Taguatinga. A maior participação aconteceu na unidade Taguatinga (38\%), e a participação da unidade Ceilândia foi a menos expressiva (13\%). As unidades Guará e Sobradinho representaram, respectivamente, $28 \%$ e $22 \%$ de participação. A faixa etária predominante dos sujeitos do estudo esteve entre 18 e 25 anos $(31 \%)$, e as demais faixas representaram 25\% (26-30), 16\% (31-35), $16 \%$ (36-40), e 13\% (acima de 40). A participação de colaboradores do seguimento feminino foi bem superior, com 63\%. A maioria dos colaboradores que participaram da pesquisa (28\%) estão no Grupo Projeção entre 3 e 4 anos.

Sobre o conjunto de questões que direcionaram aos aspectos relacionados à Comunicação Organizacional, todos os colaboradores que participaram da pesquisa reconhecem os canais de comunicação do Grupo Projeção (e-mail corporativo, portal acadêmico, ambiente de educação a distância, sistemas de apoio acadêmico-administrativo, blog), sendo que $88 \%$ dos colaboradores consideram que têm acesso a todos os canais de comunicação que necessitam para realizar suas atividades laborais. Os sistemas informatizados utilizados são suficientes para manter uma comunicação segura, objetiva, e que gere resultados desejados, segundo $59 \%$ dos colaborados.

Quase todos os colaboradores (94\%) entendem o fluxo das mensagens mediadas pelos canais de comunicação que utilizam em suas atividades. Ainda assim, 09\% dos colaboradores não sabem de onde vêm os insumos (informações) que necessitam para realizar suas atividades diárias e $22 \%$ não sabem para onde vão, ou quem vai utilizar, as informações que geram. Quando os colaboradores têm dúvidas sobre como realizar os seus procedimentos operacionais, $50 \%$ recorrem aos manuais e $50 \%$ recorrem aos pares, ou a quem julgue ser detentor de tal informação.

Considerando que a comunicação formal pode ser aquela mediada de forma organizada, controlada e gerenciada, e que a comunicação informal é aquela mediada sem o auxílio de uma ferramenta de controle, $88 \%$ dos colaboradores pensam que a comunicação formal ainda é mais eficaz em termos de objetividade, tempo e qualidade das mensagens. Porém, quando questionados sobre a maior parte de sua comunicação sobre suas atividades de trabalho com seus pares e superiores, $66 \%$ responderam que é formal, registrada ou protocolada, e 34\% responderam que é informal, sendo mais rápida a comunicação verbal.

As abordagens identificadas na literatura consultada para este estudo conduzem à visão de que a Comunicação Organizacional está relacionada diretamente à comunicação formal. Entretanto, a comunicação informal tem destacado o seu valor, sobretudo pelo auxílio das novas tecnologias que ampliam, facilitam, agilizam e podem garantir a integridade das mensagens mediadas entre os colaboradores. Barichello et al. (2002) reforçam a importância do estudo da comunicação informal no contexto das organizações, apontando a necessidade de considera-la na comunicação estratégica, considerando a subjetividade dos membros da organização e suas interpretações sobre as informações mediadas em 
diferentes níveis hierárquicos. A incidência de comunicação formal ou informal pode variar em função da Cultura Organizacional.

A qualidade das mensagens mediadas nos processos de Comunicação Organizacional dos colaboradores foi questionada. Para $40 \%$ dos colaboradores (14 respondentes), existe uma qualidade mediana das mensagens. Os demais respondentes julgaram a qualidade das mensagens como eficaz (43\%) ou totalmente eficaz (17\%). As considerações sobre a acessibilidade e apreensibilidade dos manuais, normas, regulamentos e demais documentos necessários para a realização de suas atividades laborais apresenta eficácia confirmada por $77 \%$ dos colaboradores.

Sobre Aprendizagem Organizacional, 75\% dos colaboradores conhecem os objetivos estratégicos do Grupo Projeção, e todos (100\%) entendem a importância do trabalho em equipe e do compartilhamento de informações para aumentar a produtividade. $91 \%$ dos colaboradores percebem que os resultados das pesquisas realizadas na IES são divulgados e compartilhados e $71 \%$ têm a oportunidade de utilizar tais resultados em seus planejamentos.

Todos os colaboradores que participaram da pesquisa conseguem ter uma visão sistêmica sobre os processos envolvidos em suas atividades diárias, sendo que $69 \%$ apontam que isso é resultado de proatividade em buscar informações que não Ihes são compartilhadas, e os demais (31\%), aceitam a visão sistêmica como resultado das explicações sobre os manuais e normas que a IES realiza como procedimento de contratação de novo colaborador.

Segundo Antonello (2005), a Aprendizagem Organizacional reconhece uma gama extensiva de fatores, como estratégia da organização, cultura, estrutura, capacidade de absorção, resolução de problemas, competência, participação dos funcionários, etc., determinando os resultados da aprendizagem. A distinção mais significativa entre autores que escrevem sobre aprendizagem organizacional pode ser resumida de acordo com a ênfase que esses autores atribuem à aprendizagem organizacional: como processo técnico (prescritivo ou incremental) ou processo social (descritivo).

Nonaka e Takeuchi (2004, p. 25) afirmam que:

O conhecimento é criado apenas pelos indivíduos. Em outras palavras, uma organização não pode criar conhecimento por si mesma, sem os indivíduos. É muito importante, portanto, que a organização apoie e estimule as atividades criadoras de conhecimento dos indivíduos ou que proporcione os contextos apropriados para elas. A criação do conhecimento organizacional deve ser entendida como um processo que "organizacionalmente" amplifica o conhecimento criado pelos indivíduos e o nível do grupo através do diálogo, discussão, compartilhar de experiência, fazer sentido ou comunidade de prática.

Assim, considerando as questões que envolvem a Gestão do Conhecimento, 94\% dos colaboradores conhecem a missão e a visão da 
IES. $87 \%$ dos colaboradores costumam registrar e gerenciar as lições aprendidas com as atividades que realiza. $68 \%$ dos colaboradores têm conhecimento de quais são os componentes dos sistemas de informações que participa, e $87 \%$ sabem a importância e a finalidade das informações que geram. 97\%observam que na IES existem formas de compartilhar os conhecimentos produzidos e manter memórias.

Assumindo que o conhecimento tácito é aquele que o colaborador carrega como resultado de suas experiências, e que o conhecimento explícito é aquele que está descrito nos manuais, por exemplo, 16\% trabalham mais com conhecimento tácito do que com explícito; $6 \%$ trabalham mais com conhecimento explícito do que tácito; e $78 \%$ trabalham com os dois tipos de conhecimento de forma equilibrada. Os processos internos da IES são bem mapeados e gerenciáveis e as evidências das informações geradas são de fácil acesso para $84 \%$ dos colaboradores.

Segundo $69 \%$ dos colaboradores, a IES aposta em pesquisa e desenvolvimento, sendo que $59 \%$ veem que a IES valoriza a criatividade, e para $65 \%$ a IES valoriza e estimula processos de inovação. $97 \%$ dos colaboradores reconhecem que sua IES valoriza o treinamento e a capacitação continuada.Todos os colaboradores $(100 \%)$ dizem que a cultura da IES permite que aprendam com as atividades que desempenham.

Os conceitos relacionados à Comunicação Organizacional tangenciam muitas vezes os conceitos da Cultura Organizacional. Scroferneker (2006), por exemplo, entende que a comunicação marca o estilo característico da organização e está marcado pela cultura, que imprime a sua identidade. A Cultura Organizacional envolve, ainda, normas, valores e comportamentos dentro das organizações.

As condutas pessoais influenciam na conduta profissional de $87 \%$ dos colaboradores e, especificamente, $84 \%$ trazem inferências de crenças e valores às suas atividades laborais. $94 \%$ dos colaboradores percebem que suas condutas profissionais influenciam na sua conduta pessoal. Os valores da IES impactam na conduta profissional de $97 \%$ dos colaboradores.

\section{Considerações finais}

No contexto das "organizações vivas", as interseções entre a Comunicação Organizacional, a Aprendizagem Organizacional, a Gestão do Conhecimento, e a Cultura Organizacional, podem representar espaços de construção de conhecimento. Assim, uma IES que relaciona tais características podem inserir seus colaboradores nesses espaços quando dispõem ferramentas, tecnologias e normalizações compartilhadas, acessíveis e apropriadas para cada atividade desempenhada.

A identificação e a definição de processos contribuem para dar transparência ao fluxo informacional das organizações. Mapear os processos é uma atividade que impacta diretamente na qualidade da 
organização, pois garante a continuidade de serviços e o entendimento sobre como funcionam os seus sistemas de informações.

O objetivo deste estudo foi avaliar os espaços de Comunicação Organizacional, Aprendizagem Organizacional, Gestão do Conhecimento, e Cultura Organizacional das unidades de informação que interagem diretamente com a Escola de Tecnologia da Faculdade Projeção, tendo como base um modelo de Criação de Conhecimento proposto em função da literatura consultada.

A pesquisa aponta que a IES estudada possui elementos que favorecem a Construção de Conhecimento organizacional. Os processos são bem definidos e gerenciáveis. Os canais de comunicação são efetivos e permitem a mediação de mensagens com qualidade e redução de ruídos, mesmo quando a comunicação é informal. Ainda que a estruturação dos processos seja forte, e os manuais e normas sejam a base da informação, há espaço para a socialização e respeito às crenças e valores pessoais. A IES aposta em capacitação e treinamentos continuados, o que reforça os seus pilares de Gestão do Conhecimento. Segundo os resultados da pesquisa, percebe-se que há uma relevante ocorrência de comunicação informal e consulta aos pares, ao invés de manuais, o que talvez esteja relacionado à faixa etária predominante dos colaboradores $(18-25,31 \%)$, suas subjetividades e modelos mentais diferenciados de Geração Z. Entretanto, essa consideração demanda uma reflexão mais detalhada e uma pesquisa científica aprofundada que inclua essas variáveis.

\section{Referências}

ARGYRIS, C. On organizational learning. Cambridge: Blackwell, 1995.

ANTONELLO, C. S. A metamorfose da aprendizagem organizacional: uma revisão crítica. In: RUAS, $\mathrm{R}$. et al. Os novos horizontes da gestão: aprendizagem organizacional e competências. São Paulo: Artmed, 2005. p. $12-33$.

BARICHELLO, E. M. R. et al. Comunicação informal e cultura organizacional. Revista Comunicação Organizacional, v. 1, n. 1, p. 1-10, 2002.

BASTOS, A. V. B. et al. Aprendizagem organizacional versus organizações que aprendem: características e desafios que cercam essas duas abordagens de pesquisa. Revista de Administração, v. 39, n. 3, p. 220230, 2004.

BOUTHILLIER, F.; SHEARER, K. Understanding knowledge management and information management: the need for an empirical perspective. Information Research, v. 8, n. 1, p. 141, 2002.

CHILD, J. et al. Cooperative strategy: managing alliances, networks, and joint ventures. 2. ed. New York: Oxford, 2005. 
$\mathrm{CHOO}, \mathrm{C}$. W. Working with knowledge: how information professionals help organizations manage what they know. Library Management, v. 21, n. 8, p. 395-403, 2000.

COOK, S.; YANOW, D. Culture and organizational learning. Journal of Management Inquiry, Newbury Park, v. 2, n. 4, p. 373-390, 1993.

CURRAL, L.; CHAMBEL, M. J. Processos de comunicação nas organizações. In: FERREIRA, J. M. C. et al.(Coord.). Manual de Psicossociologia das Organizações. Lisboa: McGraw Hill, 2001. cap. 13. p. 405-427.

DEETZ, S. Conceptual foundations. In: JABLIN, F. M.; PUTNAM, L. L. (Orgs.). The new handbook of organizational communication: advances in theory, research, and methods. Thousand Oaks: CA, 2001, p. 3-46.

DIBELLA, A. J. et al. Organisational learning style as a core capability. In: MOINGEON, B.; EDMONDSON, A. (Orgs.). Organisational learning and competitive advantage. London: Sage, 1996, p. 361-379.

FLORES, F. Creando organizaciones para el futuro. 5. ed. Santiago, Chile: Dolmen Ediciones, 1997.

FREITAS, I. A.; BRANDÃO, H. P. Trilhas de aprendizagem como estratégia para desenvolvimento de competências [Resumo]. In: ENCONTRO DA ASSOCIAÇÃO NACIONAL DE PÓS-GRADUAÇÃO E PESQUISA EM ADMINISTRAÇÃO, 29., Brasília: ANPAD, 2005..

GARVIN, D. Building a learning organization. Harvard Business Review, Boston, v. 71, n. 4, p. 78-91, jul./ago, 1993.

GASQUE, K. C. G. D.; COSTA, S. M. de S. Evolução teórico-metodológica dos estudos de comportamento informacional de usuários. Ciência da Informação, v. 39, n. 1, p. 21-32, jan./abr. 2010.

GIBSON, J. L. et al. Organizações: comportamento, estrutura, processos. São Paulo: Atlas, 1981.

GIL, A. C. Como elaborar projetos de pesquisa. São Paulo: Atlas, 1991.

GUIMARÃES, T. de A. Ambiente de aprendizagem e cultura em organizações: estudo de caso em organização militar. Revista de Administração, São Paulo, v. 39, n. 3, p. 231-241, 2004.

GUTIÉRREZ, M. P. M. O conhecimento e sua gestão em organizações. In: TARAPANOFF, K. (Org.). Inteligência, informação e conhecimento. Brasília: IBICT, UNESCO, 2006. p. 117-155.

IASBECK, L. C. A. A cultura organizacional na comunicação empresarial. São Paulo: Intercom, 1999.

KANUKA, H.; ANDERSON, T. Online social interchange, discord, and knowledge construction. Journal of Distance Education, v. 13, n. 1, p. 57-74, 1998.

KUNSCH, M. M. K. Planejamento de relações públicas na comunicação integrada. São Paulo: Summus, 2003. 
MARTINS, G. de A. Manual para elaboração de monografias e dissertações. 3. ed. São Paulo: Atlas, 1994.

MEDRANO, J. A. V. Comunicação organizacional integrada: alicerce intrínseco da economia de comunhão. 2007. 265f. Tese (Doutorado em Ciências da Comunicação) - Programa de Pós-Graduação em Ciências da Comunicação, Escola de Comunicações e Artes, Universidade de São Paulo, São Paulo, 2007.

MOROSINI, M. C. et al. A expansão da educação superior no Brasil pós LDB/96: organização institucional e acadêmica. Inter-Ação, Goiânia, v. 36, n. 1, p. 119-140, jan./jun. 2011.

NONAKA, I; TAKEUCHI, H. Criação de conhecimento na empresa. Rio de Janeiro: Campus, 1997.

NONAKA, I; TAKEUCHI, $H$. Criação dialética do conhecimento. In: NONAKA, I; TAKEUCHI, H. Gestão do conhecimento. São Paulo: Artmed, 2004.

QUINN, J. B. Intelligent enterprises. New York: Free Press, 1992.

QUINN, J. B. et al. Innovation explosion: using intellect and software to revolutionize growth strategies. New York: Free Press, 1997.

RICA E. Gestión del conocimiento: caminando hacia las organizaciones inteligentes. 2003. Disponível em: <http://aulauvs.sld.cu/file.php/2/gerencia/1bibli/gestionRica.doc>. Acesso em: 5 jun. 2013

ROCHA NETO, I. ; CARNEIRO, A. Gestão do conhecimento nas IES confessionais e comunitárias. Ensino Superior (ABMES), v. 25, p. 41-60, 2007.

SCHEIN, E. H. Organizational culture and leadership: a dynamics view. San Francisc: Jossey Bass, 1985.

SCROFERNEKER, C. M. A. Trajetórias teórico-conceituais da comunicação organizacional. FAMECOS, Porto Alegre, n. 31, p. 47-53, dez. 2006.

SENGE, P. M. A quinta disciplina: arte, teoria e prática da organização de aprendizagem. 10.ed. São Paulo: Best Seller, 1995.

SHRIVASTAVA, P. A typology of organizational learning systems. Journal of Management Studies, v. 1, n. 20, p. 7-28, 1983.

SILVA, N. As interseções entre cultura e aprendizagem organizacional. Convergencia Revista de Ciencias Sociales. v. 8, n. 26, p. 55-76, 2001.

SILVA, S. L. Gestão do conhecimento: uma revisão crítica orientada pela abordagem da criação do conhecimento. Ciência da Informação, v. 33, n. 2, p. 143-151, maio/ago. 2004.

SILVA, S. L. Informação e competitividade: a contextualização da gestão do conhecimento nos processos organizacionais. Ciência da Informação, Brasília, v. 31, n. 2, p. 142-151, maio/ago. 2002. 
SILVA, E. L. Metodologia da pesquisa e elaboração e dissertação. 4. ed. Florianópolis: UFSC, 2005.

THOMKE, S.; REINERTSEN, D. Agile product development; managing development flexibility in uncertain environments. California Management Review, v. 41, n. 1, p. 8-30, 1998.

TUBBS, S. L.; MOSS, S. Human communication: principles and contexts. 9. ed. Boston: McGraw-Hill, 2003.

WILSON, T. D. The nonsense of "knowledge management". Information Research, v. 8, n. 1, p. 144, out. 2002. 